\title{
The expanding frontiers of international law in the fight against corruption
}

by Dayanath Jayasuriya

The designation of December 9 each year as Global Anti-Corruption Day signifies that corruption has reached alarming levels warranting the urgent attention of the world community.

T he phenomenon of corruption is not new; nor are national legal measures to prosecute and punish offenders. What is new is the exponential growth in studies in the recent past highlighting the negative impact of corruption on national development. With billions of dollars meant for public programmes being channeled to enrich corrupt politicians, public servants and others in authority, society has been paying a heavy price in terms of denied access to essential services; inordinate delays; provision of substandard or defective or inappropriate products or services; and even danger to life and property.

It is difficult to quantify the extent of annual worldwide transactions tainted by corruption; according to Daniel Kaufmann, Director of Global Programmes at the World Bank, the figure is a staggering $\$ 1$ trillion (Kaufman D "Back to Basics - 10 Myths about Governance and Corruption", Finance and Development, Vol 42 (3), 2005). What is beyond quantification, however, is the extent of "damage" in terms of the undermining of political and social systems, value systems and good governance coupled with danger to physical life, particularly in infrastructure projects where construction defects that are glossed over pose a hazard. United Nations Secretary General Kofi Annan in his statement on the adoption by the General Assembly of the UN Convention against Corruption referred to "corruption" as "one of the biggest obstacles to development" (Annan K, Statement of the Secretary General on the Adoption by the General Assembly of the United States Convention against Corruption, New York, October 31, 2003). The World Bank estimates that one Asian country has lost almost US $\$ 40$ billion over the past two decades to corruption - see "Fact Sheet: United Nations Convention against Corruption". UNIS/CP/484 of May 10, 2004. The Independent Expert Commission headed by Paul Volcker on the United Nations Oil-forFood Programme found evidence of $\$ 1.8$ billion in kickbacks to the Iraqi government by oil companies and 2,235 suppliers (Independent Inquiry Commission. "Report on the Manipulation of the United Nations Oil-
for-Food-Programme", 2005). The World Bank/IMF Global Monitoring Report 2006 on the Millennium Development Goals, for instance, contains a special chapter on anti corruption efforts, thus underlining the significance of such efforts to accelerate development.

\section{UN CONVENTION AGAINST CORRUPTION}

The United Nations Convention against Corruption was adopted by the United Nations General Assembly in October 2003, signed in December 2003 and came into force on December 14, 2005 when the thirtieth state ratified it. Preparatory work on it commenced in 2000 when the General Assembly underlined the need for a special treaty on corruption. This was against the background of two previous treaties, namely the 1988 United Nations Convention against Illicit Traffic in Narcotic Drugs and Psychotropic Substances and the 1999 United Nations Convention against Transnational Organized Crime (which came into effect in 2003), which sought to address some of the criminal law issues pertaining to money laundering, drug trafficking, and organized crime. There was consensus that given the multifaceted ways in which corrupt practices occur and are concealed, a comprehensive treaty was necessary to complement instruments adopted by geopolitical groupings and business organizations.

The new Convention has 71 Articles divided into eight chapters (General provisions; Preventive measures; Criminalization and law enforcement: International cooperation; Asset recovery; Technical assistance and information exchange; Mechanisms for implementation; Final provisions)

\section{Objectives of the Convention}

Article 1 sets out the purposes of the Convention, namely

(a) to promote and strengthen measures to prevent and combat corruption more efficiently and effectively; 
(b) to promote, facilitate and support international cooperation and technical assistance in the prevention of and fight against corruption, including in asset recovery; and

(c) to promote integrity, accountability and proper management of public affairs and public property.

With a view to facilitating the achievement of the above objectives, the Convention requires state parties to introduce several legislative, judicial and administrative measures. These are set out in the various Articles; some requirements are new, while others find expression to varying extents in existing instruments, policies and practices.

\section{Preventive measures}

While many countries have laws and codes of conduct prohibiting bribes being sought or offered, the Convention is unique in that it calls for the adoption of comprehensive anti-corruption policies and measures to address some of the underlying causes that encourage or facilitate corrupt practices. Public service, in particular, has received special attention. In order to facilitate the "correct, honourable and proper performance of public functions," reforms are mandated in relation to human resources, working environment and operational modalities. Reforms are also mandated in areas such as public procurement, budgeting, accounting and auditing, and disclosure of assets and liabilities of public officials. Transparent, honest and efficient public services offer fewer opportunities for corruption: this commonsense perception has been confirmed by the experience of a limited number of countries that have gone through the difficult process of reforming and modernizing administrative systems.

One of the important and controversial articles in the Convention is Article 12 dealing with the "private sector". State parties are required to take measures to prevent corruption involving the private sector, including the enhancement of accounting and auditing standards in the sector and disallowing tax deductions for expenses that constitute bribery. In order to implement, monitor and coordinate the preventive anti-corruption policies and practices, the Convention requires state parties to ensure the existence of an independent and effective mechanism that can function without being unduly influenced.

\section{Criminalization and law enforcement}

The Convention goes beyond the traditional definition of "bribery" and encompasses acts such as trading in influence, abuse of functions and embezzlement of property in the private sector. Laundering the proceeds of bribery is required to be made a criminal offence.

Several law enforcement issues are addressed in the Convention, including the desirability of considering corruption as a relevant factor in legal proceedings to annul or rescind a contract. Protection of whistle-blowers receives special mention: Article 33 states that each state party shall consider incorporating into their legal systems appropriate measures to provide protection against unjustified treatment for any person who reports in good faith and on reasonable grounds to the competent authorities any facts concerning offences established in accordance with this Convention. As is the case with this particular Article, there are some Articles which do not make it mandatory for state parties to introduce relevant measures. The wording "shall consider..." requires that consideration be given to the matter and further action, if any, is discretionary.

State parties are required to ensure the existence of a body or bodies or persons specializing in combating corruption through law enforcement. The Convention has underlined the need for independence and to be able to act effectively without any undue influence.

\section{Asset recovery}

The Convention provides for the return of assets to the requesting state. These provisions constitute a watershed in the evolution of international law principles and procedures providing for the return of assets. The Convention calls for enhanced due diligence within financial institutions with regard to the identity of beneficial owners and transfer of funds by or on behalf of persons who have been entrusted with prominent public functions.

\section{International cooperation}

There are binding obligations on state parties to cooperate with each other with respect to investigations, collection of evidence, extradition and related matters. One of the most detailed Articles in the entire Convention is Article 46, which deals with mutual legal assistance.

The Convention provides for joint investigations, as well as for the use of special investigative techniques. Given the transnational significance in the movement of funds and other assets, no one country can tackle the problem on its own.

\section{Other matters addressed in the Convention}

The obligations set out in the Convention are the minimum requirements and state parties may impose stricter or severe requirements. Arbitration is provided for the settlement of disputes between states concerning the interpretation or application of the Convention. If arbitration does not take place within six months of the request, a state party to the dispute may refer the matter to the International Court of Justice.

An interesting innovation to be found in this Convention is the requirement to convene a conference of the state parties to the Convention "to improve the capacity of and cooperation between state parties to achieve the objectives 
set forth in this Convention and to promote and review its implementation" (Art 63). The Convention has underlined the need for technical and financial assistance to countries to enable such countries to effectively implement the treaty obligations. State parties are encouraged to make voluntary contributions to the United Nations Office on Drugs and Crime to support in-country and regional progammes and projects.

\section{Private sector: past victim, new ally}

Recognition of the role of the business community and the private sector in addressing the issue of corruption has added a new dimension to the global fight against corruption. In 2004, a new principle was added to the United Nations Global Compact that has some 2,500 participants, including most major companies. Principle 10 states thus:

"Business should work against corruption in all its forms, including extortion and bribery".

This principle builds on previous declarations and commitments such as the following:

- Convention on Combating Bribery of Officials in International Business Transactions (OECD);

- Rules of Conduct to Combat Extortion and Bribery (International Chamber of Commerce);

- Business Principles for Countering Bribery (Transparency International and Social Accountability International); and

- Principles for Countering Bribery (World Economic Forum's Partnering Against Corruption Initiative).

With public-private sector networking being fostered, private sector institutions are increasingly called upon to participate in bidding for projects, executing outsourced tasks and working in tandem in areas where such institutions have a comparative advantage. In order to counter bribery, private sector institutions need to identify situations or circumstances which make these institutions particularly vulnerable as they operate in different countries and in different sectors and develop in-house policies and plans of action tailored to address the issue of bribery whenever and wherever it may occur.

In the past, multinational operators in particular encountered problems when substantial donations for party funds and payments to politicians and high level officials were solicited. Non-compliant companies often lost business opportunities. So called "facilitation payments" - payments to expedite approvals or authorizations for which there is a legal right or expectation such as visa or work permit approvals, import or export licences - have been the focus of much discussion in some countries. In 1977, the US Congress enacted the Foreign Corrupt Practices Act, which outlawed such payments by US companies to foreign government officials, but there was an interesting exemption in respect of payments to low level officials to expedite routine approvals or processes.

This exemption has come under criticism since most countries do not permit such payments under domestic legislation, and many reputable multinational companies have in-house policies which also do not permit them, or require a policy statement of the exceptional situations that may warrant payments of this nature (see ERC Fellows Program, "Facilitation Payments: Whether considered custom or bribery, they put companies in a precarious position", Ethics Resource Center, Washington DC, 2003).

Fighting a bureaucracy where corruption is rampant is not easy; it is all the more difficult for outsiders without strong political or diplomatic backing or domestic connections. In countries where there is an administrative ombudsman with jurisdiction to entertain complaints of delays or obstruction, foreign business operators may find it easier to avoid making facilitation payments.

However, the institution of ombudsman has not been a success story everywhere. Unlike non-compliance with court orders which usually entail contempt of court proceedings, a corrupt administrator may remain oblivious with impunity to an order of the ombudsman unless the law mandates strict compliance within a prescribed period of time.

Article 21 deals specifically with bribery in the private sector. Most of the other Convention provisions also apply to private sector institutions, both domestic and foreign, and such institutions are now under a legal duty to develop in-house policies and practices compliant with the treaty obligations. Foreign businesses which are pressurized into offering illegal payments can rely upon the treaty provisions prohibiting them from making such payments. It is a policy that must gain universal acceptance and non-compliant foreign companies must be subjected to a "name-andshame" form of sanction. An in-house policy that requires publication of payments may have a deterrent effect, as bribe seekers wish to remain anonymous.

\section{FUTURE CHALLENGES}

The future challenge lies in developing and enforcing domestic legal instruments and having effective and autonomous institutions to monitor, detect and prosecute offenders, whether they be individuals or corporations. There must be effective systems for collecting and analyzing evidence, with able and well trained prosecutors to present the cases and an independent and fearless judiciary to hear and determine cases impartially and expeditiously. Deterrent sentences, as well as other punitive measures such as the confiscation of ill gotten gains and the blacklisting of companies, will help to send a message that it is simply not worth breaking the law. Above all, good governance in administration encompassing all 
levels and all players is needed. As Vito Tanzi has pointed out:

"Corruption is not distinct from and independent from the reform of the state, because some of the measures to reduce corruption are at the same time measures that change the character of the state ("Corruption Around the World: Causes, Consequences, Scope and Cures”, IMF Staff Papers, Vol. 45 (4), 1998, p 588).”

Honesty and integrity are not virtues that can be imposed through an international treaty. These are values that need to be inculcated and passed on from one generation to the next. The time has come for each country to demonstrate that its people have the strength of character to follow norms of good governance, not just for the sake of doing so but because of a moral imperative to do the best for the present and future generations with a view to enriching life to a high degree of excellence. A "society without corruption" should not remain a Utopian ideal to be attained only in the Lost Horizon's mythical state of Shangri-La.

\section{Dr Dayanath Jayasuriya}

Visiting Professor of Mercantile Law, University of the Free State, South Africa and former Chairman, Securities and Exchange Commission and Insurance Board of Sri Lanka 